\title{
PERBEDAAN PENGUASAAN KONSEP BIOLOGI DAN KEMAMPUAN BERPIKIR KRITIS SISWA KELAS X PADA PENERAPAN MODEL PEMBELAJARAN KOOPERATIF TIPE GROUP INVESTIGATION DAN GUIDED INQUIRY DI MAN 1 PRAYA
}

\section{A MASTERY OF BIOLOGICAL CONCEPT AND CRITICAL THINKING ABILITY DIFFERENCES OF GRADE TEN STUDENT OF MAN 1 PRAYA ON THE IMPLEMENTATION OF COOPERATIVE- BASED LEARNING GROUP INVESTIGATION TYPE AND GUIDED INQUIRY-BASED LEARNING}

\author{
Zahratul Aini, Agus Ramdani, Ahmad Raksun* \\ Program Studi Pendidikan Biologi, Fakultas Keguruan dan Ilmu Pendidikan, Universitas Mataram. \\ Jalan Majapahit no 62 Mataram, Lombok, 83125, Indonesia \\ *Email: ahmadunram@unram.ac.id
}

Diterima: 22 Februari 2018. Disetujui: 28 Maret 2018. Dipublikasikan: 31 Maret 2018

\begin{abstract}
Abstrak: Penelitian ini bertujuan untuk mengetahui perbedaan penguasaan konsep biologi dan kemampuan berpikir kritis siswa kelas X pada penerapan model pembelajaran kooperatif tipe group investigation dan model pembelajaran guided inquiry di MAN 1 Praya tahun ajaran 2016/2017. Desain penelitian ini adalah pre-test and post-test non equivalent control group design. Populasi dalam penelitian ini yaitu siswa kelas X MAN 1 Praya tahun ajaran 2016/2017 yang berjumlah 247siswa. Pengambilan sampel dilakukan dengan Purposive Sampling sehingga didapatkan kelas X MIPA-3 sebagai kelas eksperimen 1 dan kelas X MIPA-4 sebagai kelas eksperimen 2. Instrumen yang digunakan untuk memperoleh data yaitu tes penguasaan konsep berupa soal pilihan ganda dan tes kemampuan berpikir kritis berupa soal essay. Data hasil tes penguasaan konsep biologi dan tes kemampuan berpikir kritis dianalisis menggunakan uji-t pada taraf kepercayaan $95 \%$. Hasil penelitian menunjukkan bahwa ada perbedaan penguasaan konsep biologi dan kemampuan berpikir kritis siswa kelas X pada penerapan model pembelajaran kooperatif tipe group investigation dan model pembelajaran guided inquiry di MAN 1 Praya tahun ajaran 2016/2017.
\end{abstract}

Kata kunci: Kooperatif Tipe Group Investigation, Guided Inquiry, Konsep Biologi, Berfikir Kritis

\begin{abstract}
The aim of this research was to know the differences in the mastery of biological concept and critical thinking ability of grade ten student of MAN 1 Praya on the implementation of cooperative-based learning group investigation type and guided inquiry-based learning in the academic year 2016/2017. The design of this research was pre-test post-test non-equivalent control group design. The population of this research was all students of grade ten MAN 1 Praya which amounted to 247 students. The samples were taken by using purposive sampling in which students grade X MIPA-3 and X MIPA-4 became the first and second experimental classes. The research instruments were a multiple choice and an essay test.The data of mastery of biological concept and critical thinking ability were analyzed by using t-test on $95 \%$ trust level. The result of research showed that there are differences in the mastery of biological concept and critical thinking ability of students grade ten MAN 1 Praya on the implementation of cooperative-based learning group investigation type and guided inquiry-based learning in the academic year 2016/2017.
\end{abstract}

Keywords: Cooperative Group Investigation Type, guided inquiry, biological concept, critical thinking ability

\section{PENDAHULUAN}

Pembelajaran biologi hendaknya tidak lagi terlalu berpusat pada guru melainkan harus lebih berorientasi pada siswa. Penguasaan konsep siswa dapat diartikan sebagai suatu hasil pemikiran kognitif siswa melalui kegiatan atau proses belajar, sehingga dapat disebut sebagai hasil belajar kognitif [1]. Kemampuan berpikir siswa dapat ditingkatkan dengan cara mengkondisikan proses belajar tanpa banyak menggunakan hafalan tetapi siswa diberikan permasalahan untuk meningkatkan kemampuan berpikir. Kemampuan berpikir kritis dan kreatif siswa dapat dilatih dengan pembelajaran yang menuntut siswa untuk melakukan eksplorasi, inkuiri, penemuan dan memecahkan masalah serta melalui belajar dalam kelompok kecil. Berpikir kritis adalah sebuah proses sistematis yang memungkinkan siswa merumuskan dan mengevaluasi keyakinan dan pendapat mereka sendiri dalam suatu kesimpulan [2-4].

Model pembelajaran kooperatif tipe Group Investigation merupakan model pembelajaran yang mendorong siswa untuk berpikir dalam tim secara kritis, kreatif, dan analitis [5-8]. Selain model 
pembelajaran kooperatif tipe GI, model pembelajaran lain yang mampu meningkatkan penguasaan konsep dan kemampuan berpikir kritis siswa adalah model pembelajaran Guided Inquiry. Strategi pembelajaran inkuiri adalah rangkaian kegiatan pembelajaran yang menekankan pada proses berpikir secara kritis dan analitis untuk mencari dan menemukan sendiri jawaban dari suatu masalah yang dipertanyakan [9-10]. Berdasarkan uraian di atas maka dilakukan penelitian yang bertujuan untuk mengetahui perbedaan penguasaan konsep biologi dan kemampuan berpikir kritis siswa kelas $\mathrm{X}$ pada penerapan model pembelajaran kooperatif tipe group investigation (GI) dan model pembelajaran guided inquiry di MAN 1 Praya tahun ajaran 2016/2017

\section{METODE PENELITIAN}

Penelitian ini telah dilaksanakan di MAN 1 Praya Kabupaten Lombok Tengah Propinsi NTB pada bulan Mei sampai dengan Juni semester II tahun ajaran 2016/2017. Variabel bebas penelitian ini adalah model pembelajaran kooperatif tipe Group Investigation dan model pembelajaran guided inquiry dan variable terikat adalah penguasaan konsep biologi dan kemampuan berpikir kritis siswa. Populasi penelitian adalah seluruh siswa kelas $\mathrm{X}$ MAN 1 Praya yang terdiri dari 6 kelas dengan jumlah siswa keseluruhan adalah 247 orang. Sampel penelitian diambil dengan teknik purposive sampling sehingga diperoleh kelas $\mathrm{X}$ MIPA-3 dijadikan kelas eksperimen I yang diberikan model pembelajaran kooperatif tipe Group Investigation dengan jumlah siswa 42 orang dan kelas X MIPA-4 dijadikan kelas eksperimen II yang diberikan model pembelajaran Guided Inquiry dengan jumlah siswa 42 orang. Instrumen yang digunakan untuk mengukur ketercapaian penguasaan konsep biologi siswa adalah tes yang berupa soal pilihan ganda. Setiap soal memiliki 5 alternatif jawaban (a, b, c, d dan e). Instrumen yang digunakan untuk mengukur kemampuan berpikir kritis siswa adalah tes yang berupa soal essay. Data yang diperoleh dianalisis menggunakan uji $\mathrm{t}$ [11].

\section{HASIL DAN PEMBAHASAN}

Hasil tes penguasaan konsep biologi siswa sebelum diberikan perlakuan untuk kelas eksperimen I diperoleh nilai rata-rata pre-test yaitu sebesar 38,93 dan kelas eksperimen II diperoleh nilai rata-rata pre-test 38,10. Pada kelas eksperimen I diperoleh nilai pre-test tertinggi yaitu 55 dan nilai pre-test terendah yaitu 20. Kelas eksperimen II diperoleh nilai pre-test tertinggi yaitu 55 dan nilai pre-test terendah yaitu 20. Hasil tes penguasaan konsep biologi siswa setelah diberikan perlakuan untuk kelas eksperimen I dan kelas eksperimen II didapatkan bahwa kelas eksperimen I yang menggunakan model pembelajaran kooperatif tipe
Group Investigation memiliki rata-rata hasil tes penguasaan konsep biologi yang lebih tinggi dibandingkan dengan kelas eksperimen II yang menggunakan model pembelajaran Guided Inquiry. Nilai rata-rata post-test pada kelas eksperimen I yaitu 78,93 dan nilai rata-rata post-test pada kelas eksperimen II yaitu 69,52 Nilai post-test tertinggi pada kelas eksperimen I yaitu 95 dan nilai post-test terendah yaitu 60, sedangkan pada sedangkan pada kelas eksperimen II diperoleh nilai post-test tertinggi yaitu 85 dan nilai post-test terendah yaitu 50 .

Hasil tes kemampuan berpikir kritis siswa sebelum diberikan perlakuan untuk kelas eksperimen I diperoleh nilai rata-rata pre-test yaitu sebesar 41,14 dan kelas eksperimen II diperoleh nilai rata-rata pre-test 38,50 . Pada kelas eksperimen I diperoleh nilai pre-test tertinggi yaitu 65 dan nilai pre-test terendah yaitu 19. Kelas eksperimen II diperoleh nilai pre-test tertinggi yaitu 56 dan nilai pre-test terendah yaitu 16 . Hasil tes kemampuan berpikir kritis siswa setelah diberikan perlakuan untuk kelas eksperimen dan kelas eksperimen II didapatkan bahwa kelas eksperimen I yang menggunakan model pembelajaran kooperatif tipe Group Investigation memiliki rata-rata hasil belajar biologi yang lebih tinggi dibandingkan dengan kelas eksperimen II yang menggunakan model pembelajaran Guided Inquiry. Nilai ratarata post-test pada kelas eksperimen II yaitu 67,88 Nilai post-test tertinggi pada kelas eksperimen I yaitu 94 dan nilai post-test terendah yaitu 43, sedangkan pada kelas eksperimen II diperoleh nilai post-test tertinggi yaitu 90 dan nilai post-test terendah yaitu 43 .

Analisis penguasaan konsep biologi siswa menunjukkan bahwa siswa yang mengikuti pembelajaran dengan model pembelajaran kooperatif tipe group investigation nilai rataratanya adalah 78,93 dari rata-rata awal hasil belajar siswa yaitu 38,93, sedangkan siswa yang mengikuti pembelajaran dengan model pembelajaran guided inquiry nilai rata-ratanya adalah 69,52 dari rata-rata awal hasil belajar siswa yaitu 38,10. Berdasarkan nilai rata-rata tersebut, diketahui bahwa peningkatan penguasaan konsep biologi menggunakan model pembelajaran kooperatif tipe groupinvestigation lebih baik daripada model pembelajaran guided inquiry.

Hasil tes penguasaan konsep siswa lebih tinggi pada penerapan model pembelajaran kooperatif tipe group investigation daripada model pembelajaran guided inquiry. Peningkatan ini disebabkan oleh penerapan model pembelajaran kooperatif tipe group investigation mengarahkan siswa lebih mudah memahami materi pembelajaran karena diajarkan melalui kerjasama tim atau kelompok dalam mencari informasi tentang subtopik yang diberikan oleh guru. Belajar dalam tim memungkinkan siswa lebih mengembangkan 
penalarannya pada tingkat yang lebih tinggi, karena pada saat diskusi terjadi pembagian peran dalam kelompok, sehingga membuat pembelajaran lebih menarik dan membantu terjadinya kerja sama antar anggota yang mengakibatkan tumbuhnya keaktifan siswa dalam pembelajaran [12]. Dengan demikian model pembelajaran dapat mendorong keaktifan siswa untuk menggali pengetahuannya secara mandiri dalam menacari informasi pada konsep yang sedang dipelajarinya.

Dalam penelitian ini juga ditemukan bahwa model pembelajaran kooperatif tipe GI dapat membentuk kemandirian siswa dalam berbagi tugas dalam kelompok untuk menyelesaikan tugastugas akademik yang diberikan oleh guru. Kegiatan penyelidikan yang dilakukan siswa pada penerapan strategi kooperatif GI mendukung keterampilan proses kognitif berupa penguasaan konsep yang dapat diperoleh dari hasil pencarian informasi, analisis informasi, dan menyimpulkan serta pemecahan masalah dan membuat keputusan. Pernyataan ini sesuai dengan hasil penelitian Juniartina (2015) yang menyimpulkan bahwa model pembelajaran kooperatif tipe group investigation dapat meningkatkan penguasaan konsep biologi dan kemampuan berpikir kritis siswa jika dilihat dari sintak atau langkah pembelajaran model pembelajaram group investigation yang lebih menekankan pada aktivitas siswa dan bersifat student-center [13].

Model pembelajaran guided inquiry dalam proses pembelajaran sudah berjalan dengan cukup baik, akan tetapi peningkatan penguasaan konsep siswa tidak lebih baik daripada model pembelajaran kooperatif tipe group investigation. Faktor yang menyebabkan lebih rendahnya peningkatan hasil tes penguasaan konsep siswa pada penerapan model pembelajaran guided inquiry, yaitu (1) siswa kurang siap dalam proses pembelajaran dengan penerapan model pembelajaran guided inquiry disebabkan model pembelajaran tersebut jarang diterapkan dalam materi ajar yang disampaikan oleh guru di sekolah tersebut. Kriteria keberhasilan belajar ditentukan oleh kemampuan siswa menguasai materi pelajaran, maka model pembelajaran guided inquiry akan sulit diimplementasikan oleh setiap guru. Sehingga siswa memiliki peran penting dalam hal kesiapan terhadap materi yang akan disampaikan guru sebelum penerapan model pembelajaran guided inquiry; (2) materi ajar tentang perubahan lingkungan yang diajarkan oleh guru kurang tepat untuk penerapan model pembelajaran guided inquiry karena lebih banyak materi konsep dan sulit dalam penerapan atau pengaplikasiannya dalam lingkungan, karena materi perubahan lingkungan membutuhkan waktu yang cukup lama untuk pengamatannya dari segi proses perubahannya. Sementara itu setiap langkah-langkah model pembelajaran guided inquiry mengandalkan kemampuan siswa untuk menemukan solusi dan jawaban dari masalah yang dipertanyaan guru. Seperti yang dikemukakan oleh Sanjaya bahwa pada model pembelajaran guided inquiry, materi yang disajikan guru bukan begitu saja diberikan dan diterima oleh siswa, tetapi siswa diusahakan sedemikian rupa sehingga mereka memperoleh berbagai pengalaman dalam rangka "menemukan sendiri" konsep-konsep yang direncanakan oleh guru; (3) waktu yang dibutuhkan dalam penerapan model pembelajaran guided inquiry lebih lama daripada penerapan model pembelajaran kooperatif tipe group investigation. Model pembelajaran guided inquiry memerlukan waktu yang panjang sehingga sering guru sulit menyesuaikannya dengan waktu yang telah ditentukan; dan jarangnya penerapan model pembelajaran guided inquiry dalam proses pembelajaran, sehingga siswa kurang siap dan aktif dalam proses pembelajaran dengan penerapan model pembelajaran guided inquiry.

Analisis kemampuan berpikir kritis siswa menunjukkan bahwa siswa yang mengikuti pembelajaran dengan model pembelajaran kooperatif tipe group investigation nilai rataratanya adalah 74,98 dari rata-rata awal hasil belajar siswa yaitu 41,14 , sedangkan siswa yang mengikuti pembelajaran dengan model pembelajaran guided inquiry nilai rata-ratanya 67,88 dari rata-rata awal hasil belajar siswa yaitu 38,50. Berdasarkan hasil nilai rata-rata tersebut, diketahui bahwa peningkatan kemampuan berpikir kritis menggunakan model pembelajaran kooperatif tipe group investigation lebih baik daripada model pembelajaran guided inquiry. Hasil tes kemampuan berpikir kritis siswa lebih tinggi pada penerapan model pembelajaran kooperatif tipe group investigation daripada model pembelajaran guided inquiry. Hal tersebut dapat disebabkan karena model pembelajaran kooperatif tipe GI menekankan siswa untuk melakukan penyelidikan dan pemecahan masalah terutama masalah-masalah lingkungan yang terjadi di sekitar siswa berpotensi untuk memberdayakan keterampilan berpikir siswa. Selain berpotensi untuk memberdayakan keterampilan berpikir siswa, kegiatan penyelidikan siswa yang dilakukan secara berkelompok berpotensi untuk mengembangkan ide-ide kreatif dan kritis, perluasan wawasan siswa, dan keinginan untuk berbagi pengalaman yang dialami.

Meningkatnya kemampuan berpikir kritis siswa pada penerapan model pembelajaran kooperatif tipe group investigation yang memberikan kesempatan pada siswa untuk berpikir dalam menyelesaikan masalah yang ditemukan dalam proses pembelajaran. Model kooperatif tipe group investigation siswa belajar secara berkelompok dalam aktivitas yang dirancang untuk meningkatkan penguasaan isi dari mata pelajaran dan mengembangkan kemampuan dalam proses belajar, berpikir, menyelesaikan 
masalah, berkomunikasi, kerja kelompok, managemen dan evaluasi. Model pembelajaran kooperatif tipe group investigation mengajak siswa berpikir melalaui percobaan, dalam penelitian ini percobaan yang dilakukan adalah tentang pencemaran air dalam rangka menganalisis dan menyimpulkan hasil percobaan sehingga siswa memiliki kemampuan berpikir kritis [15]. Hasil penelitian ini sesuai dengan penelitian sahfriana yang menyatakan bahwa model pembelajaran kooperatif tipe group investigation dapat meningkatkan kemampuan berpikir kritis dan keterampilan sosial siswa dalam pembelajaran biologi, karena siswa mengalami pembelajaran yang bermakna [16]. Dengan demikian model pembelajaran kooperatif tipe group investigation dapat memperbaiki kemampuan siswa untuk berargumen dalam memecahkan masalah bersama kelompoknya serta memiliki pengalaman belajar sehingga mudah memahami konssep yang sedang dipelajarinya. Ppenggunaan diri yang dipilih tim untuk penyelesaian pertanyaan membantu mengembangkan keterampilan proses kunci seperti berpikir kritis dan komunikasi. Dalam kooperatif tipe group investigation (GI), siswa menganalisis hasil eksperimen dibimbing dengan berbagai pertanyaan kritis yang berurutan dan berkesinambungan, pada akhirnya siswa dapat membuat kesimpulan dengan benar sehingga terbangun kemampuan berpikir kritis.

Kegiatan diskusi kelompok dan saling berbagi pendapat dapat melahirkan perluasan dan konflik kognitif peserta didik [15]. Penerapan strategi pembelajaran tidak hanya berguna untuk menyampaikan materi pembelajaran, tetapi hendaknya dapat melatih peserta didik untuk berpikir menggunakan struktur kognitifnya secara penuh dan terarah. Model pembelajaran kooperatif tipe GI dapat digunakan guru untuk mengembangkan kreativitas siswa, baik secara perorangan maupun kelompok [16].

\section{KESIMPULAN}

Ada perbedaan penguasaan konsep biologi dan kemampuan berpikir kritis siswa kelas $\mathrm{X}$ pada penerapan model pembelajaran kooperatif tipe group investigation dan model pembelajaran guided inquiry di MAN 1 Praya tahun ajaran 2016/2017. Peningkatan penguasaan konsep biologi dan kemampuan berpikir kritis siswa pada kelas dengan penerapan model pembelajaran kooperatif tipe group investigation lebih baik dibandingkan kelas dengan penerapan model pembelajaran guided inquiry.

\section{DAFTAR PUSTAKA}

[1] Widiadnyana, I. W., Sadia, I. W., \& Suastra, I. W. (2014). Pengaruh Model Discovery Learning Terhadap Pemahaman Konsep IPA dan Sikap Ilmiah Siswa SMP. Jurnal Pendidikan IPA Indonesia, 4(1).

[2] Zakrah, Z., Lestari, N., \& Kusmiyati, K. (2015). Pengaruh strategi pembelajaran discovery terhadap kemampuan berpikir kritis siswa pada mata pelajaran IPA kelas VIII di SMPN 3 Gunungsari tahun ajaran 2014/2015. Jurnal Pijar MIPA, 10(2).

[3] Surachman, M., Muntari, M., \& Savalas, L. R. T. (2014). Pengembangan Multimedia Interaktif Berbasis Kontekstual untuk Meningkatkan Penguasaan Konsep dan Keterampilan Berpikir Kritis Siswa Kelas XI Pada Materi Pokok Sistem Koloid. Jurnal Pijar MIPA, 9(2).

[4] Ristiasari, T., Priyono, B., \& Sukaesih, S. (2012). Model pembelajaran problem solving dengan mind mapping terhadap kemampuan berpikir kritis siswa. Journal of Biology Education, 1(3).

[5] Sri, A. A. (2012). Pengaruh penerapan model pembelajaran kooperatif gi terhadap pemahaman konsep kimia dan kemampuan berpikir kreatif siswa sman 3 denpasar. Jurnal Pendidikan IPA Indonesia, 2(1).

[6] Prihanti. 2013. Belajar dan Pembelajaran Sains. Mataram: Pustaka Reka Cipta.

[7] Gayatri, I. G. A. S., Jekti, D. S. D., \& Jufri, A. W. (2013). Efektifitas pembelajaran berbasis masalah (PBM) dan strategi kooperatif terhadap kemampuan menyelesaikan masalah dan hasil belajar kognitif biologi ditinjau dari kemampuan akademik awal siswa kelas $\mathrm{X}$ SMA Negeri 3 Mataram. Jurnal Pijar Mipa, 8(2).

[8] Fahruddin, F., Jufri, A. W., \& Jamaluddin, J. (2016). Pengaruh Model Pembelajaran Kooperatif Terhadap Hasil Belajar Kognitif Ditinjau Dari Kemampuan Akademik Mahasiswa. Erudio (Journal of Educational Innovation), 2(2), 41-48.

[9] Warsono dan Hariyanto. 2012. Pembelajaran Aktif. Bandung: PT. Remaja Rosdakarya.

[10] Yasmin, N., Ramdani, A., \& Azizah, A. (2015). Pengaruh metode inkuiri terbimbing terhadap keterampilan proses sains dan hasil belajar biologi siswa kelas VIII di SMPN 3 Gunungsari tahun ajaran 2013/2014. Jurnal Pijar MIPA, 10(2).

[11] Wahyuningsih, W., Jamaluddin, J., \& Karnan, 
K. (2015). Penerapan pembelajaran Biologi berbasis macromedia flash dan implikasinya terhadap keterampilan metakognitif dan penguasaan konsep siswa kelas VIII SMPN 6 Mataram. Jurnal Pijar MIPA, 10(1).

[12] Setyawarno, D. 2016. Panduan Statistik Terapan untuk Penelitian Pendidikan.pdf. Yogyakarta: Pendidikan IPA FMIPA UNY.

[13] Isjoni. 2009. Cooperative Learning Efektifitas Pembelajaran Kelompok. Bandung: Alfabeta.

[14] Juniartina, P. P. (2015, October). Pengaruh Model Pembelajaran Kooperatif Group Investigation Terhadap Pemahaman Konsep Dan Kemampuan Berpikir Kritis Siswa Kelas XI IA SMA Negeri 4 Singaraja. In Prosiding Seminar Nasional MIPA.
[15] Raksun, A. (2009). Implementasi Pembelajaran Kooperatif untuk Meningkatkan Motivasi Dan Hasil Belajar Mahasiswa Program Studi Pendidikan Fisika FKIP Universitas Mataram Pada Matakuliah Biologi Dasar. Jurnal pijar MIPA, 4(1).

[16] Sahfriana, I., Wachju, S., Suratno. 2015. Penerapan Model Pembelajaran Group Investigation (GI) dalam Meningkatkan Kemampuan Berpikir Kritis dan Keterampilan Sosial Siswa dalam Pembelajaran IPA Biologi untuk Materi Ajar Pertumbuhan dan Perkembangan Kelas 8-c Semester Gasal di SMP Negeri 1 Bangil Pasuruan. e-Journal Program Studi Pendidikan Biologi FKIP Unej Pancaran, 4, 2, 213-222. 